University of Pennsylvania Carey Law School

Penn Law: Legal Scholarship Repository

Faculty Scholarship at Penn Law

3-25-2019

\title{
Intermediated Securities Holding Systems Revisited: A View Through the Prism of Transparency
}

Thomas Keijser

Radboud University Nijmegen

Charles W. Mooney Jr.

University of Pennsylvania Carey Law School

Follow this and additional works at: https://scholarship.law.upenn.edu/faculty_scholarship

Part of the Banking and Finance Law Commons, Business Organizations Law Commons, Commercial Law Commons, Econometrics Commons, Finance and Financial Management Commons, Law and Economics Commons, Law and Society Commons, Securities Law Commons, and the Technology and Innovation Commons

\section{Repository Citation}

Keijser, Thomas and Mooney, Charles W. Jr., "Intermediated Securities Holding Systems Revisited: A View Through the Prism of Transparency" (2019). Faculty Scholarship at Penn Law. 2070.

https://scholarship.law.upenn.edu/faculty_scholarship/2070

This Article is brought to you for free and open access by Penn Law: Legal Scholarship Repository. It has been accepted for inclusion in Faculty Scholarship at Penn Law by an authorized administrator of Penn Law: Legal Scholarship Repository. For more information, please contact PennlawIR@law.upenn.edu. 


\title{
INTERMEDIATED SECURITIES HOLDING SYSTEMS REVISITED: A VIEW THROUGH THE PRISM OF TRANSPARENCY
}

\author{
Thomas Keijser and Charles W Mooney, Jr
}

\section{Introduction}

This chapter explores a variety of legal contexts in which intermediated securities holding systems play a significant-sometimes outcome determinative-role. It focuses in particular on the relationships between the principal attributes of information technology systems (ITSs) that implement intermediated holding systems and the legal principles that underpin these systems.

A prototypical intermediated securities holding system involves a 'tiered system' of securities holding. At the 'top' tier is a central securities depositary (CSD) that has a direct relationship with the issuers of securities that reside in the system. The CSD, itself an intermediary, has account holders (often referred to as participants) to whose securities accounts the CSD credits securities by book entries. The participants, in turn, have account holders to whose securities accounts the participants credit securities. Some of the participants' account holders also may be intermediaries that have account holders to whose accounts these intermediaries credit securities. ${ }^{1}$ Figure 1 reflects a typical, albeit simplified, intermediated holding structure. ${ }^{2}$

\footnotetext{
${ }^{1}$ This chapter primarily uses the terminology used in the UNIDROIT Convention on Substantive Rules for Intermediated Securities (Geneva Securities Convention, or GSC), such as 'securities' (Art 1(a)), 'intermediated securities' (Art 1(b)), 'securities account' (Art 1(c)), 'account holder' (Art 1(e)), 'intermediary' (Art 1(d)), 'relevant intermediary' (Art 1(g)), etc. and, where appropriate, the consistent terminology developed for this book and set out in the introductory chapter by Louise Gullifer and Jennifer Payne.

${ }^{2}$ See also Figure 2 in the introductory chapter.
} 


\section{FIGURE 1}

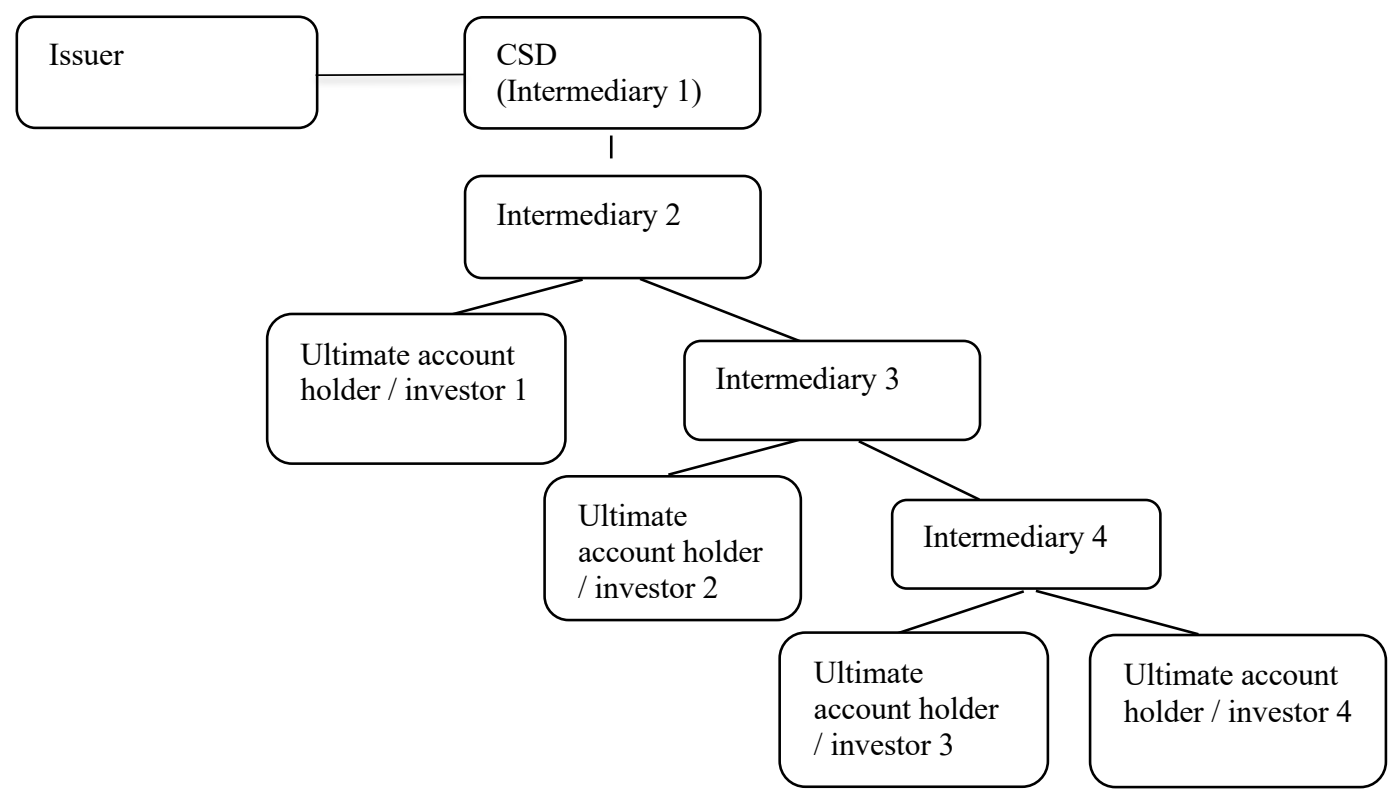

As used in this chapter, a 'transparent' ITS is a system in which the 'ultimate' account holder of securities (ie, the account holder at the 'bottom' tier) would be identified and known by each intermediary at every tier of securities holding (including at the CSD level) and by the issuer. ${ }^{3}$ Our thesis is straightforward: the implementation of a transparent ITS for an intermediated securities holding structure could provide substantial benefits. ${ }^{4}$ First, in some contexts a transparent ITS could result in improvements in the functions of intermediated holding systems even without any changes in laws or regulations. Second, adoption of a transparent ITS could provide a catalyst for the reform of the legal principles on which holding systems are based and the rules that govern their operations as well as a roadmap for the substance of such law reforms. As a corollary, the discussion illustrates that currently existing non-transparent ITSs are the source of (or at least substantially contribute to) unnecessary risks, uncertainties, and inefficiencies of intermediated holding systems. Our discussion generally assumes, except as noted, the continued existence of tiered intermediated holding systems as we know them. But among the potential areas of

\footnotetext{
${ }^{3}$ We generally use the term 'ultimate account holder', but note (as also indicated in the introductory chapter) that there may be instances where ultimate account holders act for investors or beneficiaries beyond the intermediated holding chain, eg in the context of pension or investment funds and nominee structures. For instance, in the context of the identification of 'ultimate beneficial owners' for regulatory purposes (see section III.F), there may be a need to look beyond the intermediated chain.

${ }^{4}$ In some States and markets it would not be feasible - indeed it might be wholly impractical - to adopt and implement a transparent ITS short of a wholesale revamping of the relevant intermediated holding system, including its legal underpinnings. We posit here the adoption of a transparent ITS not as a concrete proposal for actual implementation but essentially as a thought experiment for exploring the benefits of generally imposing transparency on intermediated holding systems.
} 
law reform that a transparent ITS might inspire is the prospect that securities holdings could become largely disintermediated through the application of new technologies, including 'blockchain' or distributed ledger technology (DLT). Indeed, an examination of the benefits of transparency could support the wisdom of adopting disintermediated systems and abandoning legal constructs that are based on tiers of intermediaries.

This identification of ultimate account holders contemplated by a transparent ITS would include the number/amount of each issue of securities held by each such account holder. The 'identification' contemplated by a transparent system does not necessarily mean that the particulars of an ultimate holder or its holdings would be generally available to the public or even to personnel within the intermediaries or the issuer involved, except on a 'need to know' basis. The methods of identification would be adjusted (such as by substitution of anonymous numerical identifiers of holders and holdings) as necessary in the relevant market to accommodate required protections, such as those relating to privacy or confidentiality.

By way of contrast, in a strictly 'non-transparent' ITS used in an intermediated holding system, the issuer would know the CSD and its holdings but not its participants and their holdings and the CSD would know its participants (such as Intermediary 2) and their holdings but would not know the account holders at lower levels (such as Intermediaries 3 and 4 and Ultimate account holders 1 - 4) and their holdings. ${ }^{5}$ This 'information gap' arises in non-transparent systems precisely because a relevant intermediary possesses information only with respect to its direct account holders and not with respect to account holders of other intermediaries in the tiered chain of holdings. Our thesis is based on the premise that filling this information gap by means of a transparent ITS could facilitate important and useful law reforms and could ameliorate some material flaws resulting from the application of current law in non-transparent ITSs.

Following this Introduction, section II provides an overview of various transparent and non-transparent holding systems and their underlying legal structures. Section III then considers various legal contexts in which intermediated holding systems play an instrumental role in the determination of legal rights and responsibilities. It illustrates that in many contexts the underlying goals of legal regimes are frustrated by non-transparent ITSs and their corresponding legal regimes and would be ameliorated by the adoption of

\footnotetext{
${ }^{5}$ We quite consciously distinguish ITSs, both transparent and non-transparent, from intermediated securities holding systems. References to the former are to the ITSs that possess the relevant (transparent or nontransparent) informational qualities, regardless of the legal structure. References to the latter contemplate legal structures for the holding of securities through intermediaries. Of course, a transparent (legal) intermediated securities holding system necessarily would employ a transparent ITS. We are positing here the possibility of imposing a transparent ITS on non-transparent (legal) intermediated securities holding systems.
} 
transparent principles or by directly connecting (legally and systemically) investors with issuers. Section IV explains how the adoption of a transparent ITS for an intermediated holding system could provide solutions even without legal reforms, and act as a catalyst for the adoption of such reforms and a roadmap for revision of the relevant laws. Section $\mathrm{V}$ concludes the chapter.

\section{Intermediated securities holding systems: Transparency, non-transparency, and variations on the theme}

This section provides an overview of different types of intermediated holding systems, notably transparent and non-transparent ones. This overview draws largely from the UNIDROIT Legislative Guide on Intermediated Securities (UNIDROIT Legislative Guide) and its sources, such as the preparatory work on the Geneva Securities Convention. ${ }^{6}$

There are different ways to distinguish intermediated holding systems. One important distinction relates to the legal characterisation of the relations between the participants in a particular system. The UNIDROIT Legislative Guide broadly identifies five types of legal approaches, based on respectively (i) individual ownership; (ii) co-ownership; (iii) trust; (iv) security entitlements; and (v) contract, although the UNIDROIT Legislative Guide notes that this is neither an exhaustive list nor that the models are mutually exclusive. $^{7}$

Another distinction, which is particularly relevant in the context of this chapter, is that between transparent and non-transparent systems. ${ }^{8}$ In transparent systems, the identity of ultimate account holders is known to the top level entities in the chain (the issuer and/or the CSD). In such systems, the CSD typically shares the role of maintaining a securities account with account operators (i.e. intermediaries that act as a technical interface between the CSD and ultimate account holders). The UNIDROIT Legislative Guide identifies three prototypes of transparent systems that reflect different ways in which information about the holdings of such account holders is available at the upper-tier level: (i) in an ultimate

\footnotetext{
${ }^{6}$ See UNIDROIT Legislative Guide on Intermediated Securities (UNIDROIT Legislative Guide), ss 39-56. On preparatory work regarding transparent systems resulting in Art 7 GSC, see H Kanda, C Mooney, L Thévenoz, S Béraud, assisted by T Keijser, Official Commentary on the UNIDROIT Convention on Substantive Rules for Intermediated Securities (Oxford, Oxford University Press, 2012), Int-28 to Int-30 and the commentary on Art 7, as well as the UNIDROIT preparatory documents mentioned in 7-6 and 7-7. On transparent and non-transparent systems, see also T Keijser in R Goode, H Kronke, E McKendrick (eds), Transnational Commercial Law: Texts, Cases and Materials (Oxford, Oxford University Press, 2015; 2nd edition), 15.21 .

${ }^{7}$ UNIDROIT Legislative Guide (n 6) ss 39-50. For analysis of the first four of these approaches, see also the chapter by Victoria Dixon in this volume.

${ }^{8}$ UNIDROIT Legislative Guide (n 6) ss 51-3. At times a distinction is made between direct and indirect systems, which may coincide with that between transparent and non-transparent systems; see eg ibid, s 39 . See also the chapter by Victoria Dixon in this volume.
} 
account holder's account with the CSD; (ii) in an intermediary's account with the CSD in which the holdings of ultimate account holders are identified; and (iii) in an intermediary's omnibus account with the CSD on which the account information of ultimate account holders is consolidated on a regular basis. ${ }^{9}$

Non-transparent systems, on the other hand, are characterised by a tier-by-tier analysis, under which the top level entities (the issuer and/or the CSD) only know their own holders or account holders, but not the lower-tier (including the ultimate) account holders. Inversely, in such non-transparent systems each account holder only knows its relevant intermediary, but no upper-tier entities. ${ }^{10}$

It should be noted that systems may be mixed in the sense that part of the holding chains in that system is transparent, while another part is non-transparent. Moreover, a chain that originates in a transparent system is likely to become non-transparent when it crosses the border and connects with the system in another State, a scenario that may give rise to a complex analysis. ${ }^{11}$

\section{Intermediation and transparency in context}

\section{A. Erosion of Investor Rights I: Corporate Actions}

Tiered, non-transparent systems may impede the exercise of corporate actions by account holders. ${ }^{12}$ Nora Rachman and Maria Vermaas helpfully distinguish three types of such actions, i.e. the exercise of voting rights attached to shares, the right to receive income on securities (such as dividends on shares or interest on bonds), and the provision of information from the issuer to account holders or vice versa. ${ }^{13}$ In systems in which there is no direct link between the issuer and ultimate account holders, there is often a discrepancy between the entity legally entitled to exercise corporate rights against the issuer (often a CSD or another intermediary at the top of the intermediated chain with a direct connection

\footnotetext{
${ }^{9}$ For the prototypes and accompanying diagrams, see UNIDROIT Legislative Guide (n 6) s 51. Note that the Legislative Guide uses 'investor' terminology in this context, but as explained in the Glossary on $\mathrm{p} x \mathrm{xv}$ and in para 22(c) this refers to account holders at the end of the chain. Concrete examples of transparent systems in a range of States throughout the world can be found in the UNIDROIT preparatory documents mentioned in Kanda et al (n 6) 7-6 and 7-7.

${ }^{10}$ UNIDROIT Legislative Guide (n 6) s 52.

${ }^{11}$ Ibid, ss 53-6. As pointed out in the chapter by Victoria Dixon in this volume, this - absent any connecting mechanism - is a significant limitation on the transparency of holding chains, since cross-border holding is very common.

${ }^{12}$ This section focuses on the way (a lack of) transparency in the intermediated chain impacts on corporate actions processing. For an analysis of corporate governance issues in this context, see the chapter by Paul Davies in this volume.

${ }^{13}$ See N Rachman and M Vermaas, 'Corporate Actions in the Intermediated System: Bridging the Gap between Issuer and Investor' in T Keijser (ed), Transnational Securities Law (Oxford, Oxford University Press, 2014) ch 6. The same distinction is reflected in Arts 9(1)(a) and 10(2)(e)-(f) GSC (n 1).
} 
with the issuer) and those economically entitled to such rights (the ultimate account holders at the bottom of the chain). In such cases corporate actions need to be processed up and down the intermediated chain by all intermediaries between issuer and the ultimate account holder. The information gap - the issuer does not know the holder of the economic and beneficial entitlements - may (and does) lead to considerable complications in practice. ${ }^{14}$ Complications in a national setting are likely to be exacerbated in a context of cross-border intermediated chains, where different legal systems may come into play at different tiers. For this reason, the UNIDROIT Legislative Guide emphasises the importance of processing the rights attached to securities (voting and income rights, as well as rights to information) through the intermediated chain. ${ }^{15}$

In the European Union, the progressive integration of its financial markets increased the need to address this bottleneck. Two initiatives to this end are mentioned here. First, the EU Shareholder Rights Directive was recently revised, so as to improve the identification of shareholders, the transmission of information to or from the shareholder (or its nominee) through the intermediated chain, as well as the exercise of shareholder rights through the chain (including the right to participate and vote in general meetings). ${ }^{16}$ Although the new provisions of the Directive thus underline the importance of processing rights and information through the intermediated chain, this approach is not backed up by a uniform definition of shareholder, which is currently defined as 'the natural or legal person that is recognised as a shareholder under the applicable law'. ${ }^{17}$ Each Member State may thus define a shareholder on the basis of a legal criterion (in which case the shareholder may well be an upper-tier entity), an economic one (pointing at the ultimate account holder), or yet differently. This failure to harmonise the concept considerably reduces the value of the

\footnotetext{
${ }^{14}$ For a transnational perspective, see Rachman and Vermaas (n 13). For analysis of complications in the US system, see D Donald, The Rise and Effects of the Indirect Holding System: How Corporate America Ceded Its Shareholders to Intermediaries (September 2007), available at https://papers.ssrn.com/sol3/papers.cfm?abstract id=1017206; D Donald, 'Heart of Darkness: The Problem at the Core of the US Proxy System and Its Solution', (2011) 6/1 Virginia Law \& Business Review 41; M Kahan and E Rock, 'The Hanging Chads of Corporate Voting', (2008) 96 The Georgetown Law Journal 1227; GS Geis, Traceable Shares and Corporate Law (February 2018), available at https://papers.ssrn.com/sol3/papers.cfm?abstract_id=3129042, especially I. For background regarding the UK, see eg Department for Business Innovation \& Skills, Exploring the Intermediated Shareholding Model (January 2016; BIS Research Paper 261), available at https://www.gov.uk/government/publications/shareholding-the-role-of-intermediaries, and for detailed discussion of the position under English law, see the chapter by Paul Davies in this volume.

${ }^{15}$ See UNIDROIT Legislative Guide (n 6), especially ss 24, 30, 35, 85, 90-3, 100-01, 110-13, 230-50.

${ }^{16}$ See new Arts 3a-c of Directive 2007/36/EC (Shareholder Rights Directive), as set out in Art 1(3) of Directive (EU) 2017/828, OJ L 132/1 (20 May 2017). See second update of Rachman and Vermaas (n 13) for the Oxford Legal Research Library (March 2016) N-6-1 to N-6-5; T Kotta Kyriakou, 'Harmonizing Corporate Actions for the Achievement of a Capital Markets Union: An Analysis of the Shareholders' Rights Directive, the Green Paper "Building a Capital Markets Union" and TARGET2-Securities', (2017) 14/3 European Company Law Journal 121, s 2.

${ }^{17}$ Shareholder Rights Directive (n 16) Art 2(b). For more discussion of the Shareholder Rights Directive, see the chapter by Paul Davies in this volume.
} 
new provisions in the Directive. Second, the development of TARGET2-Securities (T2S) ${ }^{18}$ was a motor behind a drive towards harmonisation of common standards for corporate actions, notably in the form of the T2S corporate actions standards developed by the T2S Corporate Actions Sub-Group and the market standards developed by the Corporate Actions Joint Working Group. ${ }^{19}$ All these European initiatives, however, take the existence of tiered systems as a given. Their aim is not to enhance transparency of the intermediated chain, but rather to contribute to seamless cooperation of the different tiers involved.

Another major imminent development towards transparency concerns the role that distributed ledger technology (DLT) may play in the processing of corporate actions. ${ }^{20}$ The ECB Advisory Group on Market Infrastructures for Securities and Collateral noted that:

'If all actors [in the intermediated chain] are nodes participating in the DLT network, then the complexities around the processing of information up and down the chain (including all the required reconciliations and consistency checks) could be eliminated, simply by giving simultaneous, distributed access to the relevant information to all actors on the ledger. ${ }^{21}$

And that:

'The use of DLT networks for the streamlining and standardisation of all communications on corporate events originating from issuers may be a powerful tool to ensure that a single "golden copy" of all corporate events is easily produced by the originators of such information and accessible to all interested parties and users. ${ }^{22}$

Likewise, in the context of the US intermediated holding system, George Geis argues that DLT has the potential to facilitate a shift from shares held in fungible bulk to identifiable, traceable shares, and that as a result many of the current pathologies in the system from a

18 T2S is a pan-European platform for securities settlement. See https://www.ecb.europa.eu/paym/t2s/html/index.en.html.

19 See https://www.ecb.europa.eu/paym/t2s/governance/ag/html/subcorpact/index.en.html; second update Rachman and Vermaas (n 13) N-6-6 to N-6-12; Kotta Kyriakou (n 16) s 4.

${ }^{20}$ See eg CSD Working Group on DLT, General Meeting Proxy Voting on Distributed Ledger: Product Requirements v2.1 (November 2017); European Central Bank/Eurosystem, Advisory Group on Market Infrastructures for Securities and Collateral, The Potential Impact of DLTs on Securities Post-trading Harmonisation and on the Wider EU Financial Market Integration (September 2017), available at https:/www.ecb.europa.eu/paym/intro/governance/shared/pdf/201709_dlt_impact_on_harmonisation_and integration.pdf, s 9, p 114, and p 117; D Yermack, 'Corporate Governance and Blockchains', (2017) 21/1 Review of Finance 7, 3.6.

${ }^{21}$ ECB Advisory Group (n 20) s 9.2.1. While this observation may be an oversimplification by the Advisory Group, to say the least, the point is that DLT has the potential for substantially improving systems for corporate action processing.

22 ECB Advisory Group (n 20) p 117. 
corporate law point of view could be eliminated. ${ }^{23}$ The access to information for the participants on a DLT network could be combined with 'smart contracts' for the automated processing of corporate actions. ${ }^{24}$

\section{B. Erosion of Investor Rights II: 'No Look-Through' and Claims Against the Issuer and Upper-Tier Intermediaries}

The only relevant counterparty for an account holder in a non-transparent system is its relevant intermediary. Nonetheless, acts or omissions that occur at higher tiers, including at the level of the issuer, may have an impact on the account holder. For example, an issuer may provide inaccurate or deceptive information, on which an ultimate account holder bases investment decisions. In such cases, an account holder cannot, in principle, seek redress against any higher-tier entity, but may only turn to its relevant intermediary, which in turn may do the same in relation to its relevant intermediary, etc. Many intermediaries, however, contractually exclude responsibility for the acts and omissions of upper-tier entities. Moreover, there may be statutory impediments to such responsibility. As such, account holder rights may be eroded to the 'lowest common denominator' of contractual and statutory limitations at any upper tier of the intermediated chain.

This point may be illustrated with three recent English court cases. ${ }^{25}$ In Eckerle $v$ Wickeder Westfalenstahl $\mathrm{GmbH}$, three ultimate account holders at the end of an intermediated chain were denied the exercise of minority shareholder rights regarding the decision of the company issuing the shares concerning its conversion from a public limited company to a private limited company. ${ }^{26}$ Second, in Secure Capital SA v Credit Suisse AG, an ultimate account holder was likewise prevented from suing the issuer of bonds for allegedly providing misleading information in the documentation of the relevant bond issue, because

\footnotetext{
${ }^{23}$ Geis (n 14). See also the discussion about earmarking of securities in the chapter by Eva Micheler in this volume, and, for a general discussion of the part DLT can play in the holding of securities, the discussion in the chapter by Sarah Green and Ferdisha Snagg. We recognise that the adoption of DLT could facilitate corporate actions by closing the information gap through tracing. However, the persistence of non-transparent holding systems in the US cannot be attributed to any deficiencies in the available technology - as evidenced by the operation in many jurisdictions of transparent systems employing 'legacy' technology.

${ }^{24}$ See BIS Committee on Payments and Market Infrastructures (CPMI), Distributed Ledger Technology in Payment, Clearing and Settlement (February 2017), available at https://www.bis.org/cpmi/publ/d157.pdf, 3.2.5; ISDA and Linklaters, Whitepaper: Smart Contracts and Distributed Ledger: A Legal Perspective (August 2017).

${ }^{25}$ See also the chapter by Raymond Cox in this volume.

${ }^{26}$ Eckerle v Wickeder Westfalenstahl GmbH [2013] EWHC 68 (Ch). See also E Micheler, 'Transfer of Intermediated Securities and Legal Certainty' in T Keijser (ed), Transnational Securities Law (Oxford, Oxford University Press, 2014) ch 5, especially 5.10-17; E Micheler, 'Custody Chains and Asset Values: Why Crypto-securities Are Worth Contemplating' (2015) 74 Cambridge Law Journal 505, III.B.1; the chapter by Eva Micheler in this volume; J Benjamin, 'Stewardship and Collateral' (2017) 12 Capital Markets Law Journal 312, s 6.
} 
the ultimate account holder held its bonds through a multi-tiered intermediated chain. ${ }^{27}$ Third, in Re Public Joint-Stock Company Commercial Bank 'Privatbank', ultimate account holders could vote to approve a proposed scheme of arrangement, but only because several legal constructs (notably the provision of a right of direct recourse for the ultimate noteholders and a deed poll) were used in order to enfranchise them and to circumvent the approach taken in the Eckerle and Secure Capital cases. ${ }^{28}$ While careful drafting (and perhaps good fortune) rescued the account holders in Privatbank, the information gap precluded a judicial solution to the problems of the ultimate account holders in Eckerle and Secure Capital.

\title{
C. Prohibition or Conditions on Upper-Tier Attachment
}

Upper-tier attachment is another type of claim that illustrates the challenges posed by nontransparent intermediated systems. Article 22 of the GSC generally prohibits upper-tier attachment in such systems. ${ }^{29}$ This means that intermediated securities of an account holder can only be attached at the level of its relevant intermediary, but not at the level of any upper-tier intermediary or the issuer.

The prohibition of upper-tier attachment is a rule of law that is based specifically on the potential problems and risks of disruption of the holding chain caused by the information gap. The UNIDROIT Legislative Guide explains:

\begin{abstract}
'Permitting [upper-tier] attachment would undermine the ability of an intermediary to perform its functions and disrupt the integrity of the intermediated securities holding system. What should be avoided is that such an attachment order blocks securities accounts of other account holders who have nothing to do with the subject matter of the attachment. If upper-tier attachment is permitted, such blockage could happen because upper-tier intermediaries usually do not know and are unable to specify what part of the securities or intermediated securities are the relevant securities that should be subject to the attachment. ${ }^{30}$
\end{abstract}

Thus, as a result of the information gap, if upper-tier attachment were allowed, the uppertier entity might consider it necessary to freeze any further trading in relation to the entire

\footnotetext{
${ }^{27}$ Secure Capital SA v Credit Suisse AG [2015] EWHC 388 (Comm). See the chapter by Raymond Cox in this volume; Micheler 2015 (n 26) III.B.2; Benjamin (n 26) s 6.

${ }^{28}$ Re Public Joint-Stock Company Commercial Bank 'Privatbank' [2015] EWHC 3299 (Ch). See R Salter, 'Intermediated Securities and the Rights of the Ultimate Investor' (2016) Butterworths Journal of International Banking and Financial Law 153. $C f$ also R Salter, 'Misrepresentation Claims against the Issuer by Buyers in the Secondary Market: A Cautionary Tale' (2017) Butterworths Journal of International Banking and Financial Law 130, especially 133 ('[n]o relevant contract'). For discussion of the effect of intermediated holdings on schemes of arrangement, see the chapter by Jennifer Payne in this volume.

${ }^{29}$ See also Principle 8 of the UNIDROIT Legislative Guide (n 6) which is in accord.

${ }^{30}$ UNIDROIT Legislative Guide (n 6) s 200 (emphasis added).
} 
issue of the securities concerned until adequate information regarding the account holder and its holdings is available. This could have a broad detrimental effect on other entities in the market that have nothing to do with the attachment. Moreover, also as a result of the information gap, the information concerning an attachment at an upper tier may not be available to entities at lower tiers, which may continue to trade and act on account holder instructions concerning the relevant securities despite the attachment, thus further compromising the integrity of the intermediated holding system. Such complications may be exacerbated in a cross-border setting. ${ }^{31}$

Notwithstanding these concerns, the GSC recognises that the prohibition of upper-tier attachment should be relaxed and made inapplicable for jurisdictions that have adopted procedures that eliminate the information gap. Under Article 22(3) of the GSC a Contracting State may allow upper-tier attachment if it makes a qualifying declaration to that end. ${ }^{32}$ This exception to the prohibition of upper-tier attachment is particularly geared to accommodate transparent systems, but may also apply in other holding patterns, as long as 'a system is in place (through the use of information technology or otherwise) which ensures that the problems and risks that Article 22(1) is intended to prevent are adequately addressed'. ${ }^{33}$ Such problems and risks may notably be prevented, or at least reduced, where communication mechanisms or other procedures are in place which guarantee that an attachment at one level in the holding chain is known to relevant actors elsewhere in the chain.

The issue of upper-tier attachment came to the fore in Bank Markazi aka Central Bank of Iran $v$ Peterson, ${ }^{34}$ a case before the US Supreme Court that concerned victims of Iransponsored acts of terrorism, their estate representatives, and surviving family members, who wanted to attach and take recourse against bond assets of Bank Markazi, the Central Bank of Iran (which was wholly owned by the Iranian government). Bank Markazi held these assets through a chain of intermediaries: it maintained an account with Banca UBAE SpA in Italy, which was an account holder of Clearstream Banking SA in Luxembourg, which in turn held an account with Citibank NA in New York. Under the relevant generally applicable law in the US legal process against an intermediary other than a judgment debtor's relevant intermediary is strictly prohibited. ${ }^{35}$ However, a terrorism-related federal law in the US permits legal process against 'blocked assets'-which in Bank Markazi

\footnotetext{
${ }^{31}$ For further analysis of the rationale of the prohibition of upper-tier attachment, see Kanda et al (n 6) Art 22, especially 22-1 and 22-2; UNIDROIT Legislative Guide (n 6) 199-208, especially 200-02.

${ }^{32}$ Kanda et al (n 6) 22-3, 22-7, 22-19 to 22-22; UNIDROIT Legislative Guide (n 6) 203-08.

${ }^{33}$ Kanda et al (n 6) 22-21.

${ }^{34}$ Bank Markazi aka Central Bank of Iran v Peterson 578 U.S.,, 136 S.Ct. 1310, 194 L.Ed.2d 463 (2016).

${ }^{35}$ See Uniform Commercial Code (UCC) § 8-112(c) ('The interest of a debtor in a security entitlement may be reached by a creditor only by legal process upon the securities intermediary with whom the debtor's securities account is maintained...').
} 
included the assets held in the account with Citibank. ${ }^{36}$ For present purposes Bank Markazi is instructive primarily because the relevant information on the assets in question was available at the higher-tier intermediary-Citibank - so that the assets were 'blocked' without any of the disruption that the prohibition of upper-tier attachment is intended to avoid. ${ }^{37}$ And this was so even in the setting of the classically tiered, non-transparent intermediated holding system that prevails in the US under Uniform Commercial Code Article 8 and without the sort of non-Convention law framework contemplated by the declaration mechanism under Article 22 of the GSC.

Outside the narrow (but important) context of terrorism-related enforcement, ${ }^{38}$ the strict prohibition on upper-tier attachment remains the rule in US jurisdictions. That the Citibank account was 'blocked' under the federal anti-terrorist scheme involved in Markazi facilitated the identification of the assets as those of Bank Markazi, even under the existing non-transparent holding structure. Because it is demonstrably possible and feasible for a creditor to overcome the information gap in a manner that permits legal process at an upper tier without any systemic disruption or harm to third parties, it is difficult to justify the generally applicable UCC rule of complete prohibition. Relaxation of the prohibition as contemplated by Article 22 of the GSC would be a better approach, but one should not underestimate the potential for opposition from the community of securities intermediaries. ${ }^{39}$

\section{Intermediary Insolvency Risk: Prevention, Loss Sharing, and Set-Off}

An account holder-investor must take into account the prospect that the issuer of securities credited to its securities account may become insolvent, in which case the securities may well turn out to be worthless. This is so in both transparent and non-transparent intermediated holding systems as well as in the case of an investor holding certificates or directly on an issuer's registry. This risk is part and parcel of the 'issuer risk' that is inherent in an investment in a financial asset. But in intermediated holding systems there exists the

\footnotetext{
${ }^{36}$ Terrorism Risk Insurance Act of 2002 (TRIA) § 201(a), 116 Stat. 2337, note following 28 U.S.C. $\S 1610$; see TRIA § 201(d)(2) (defining 'blocked asset'); Markazi (n 34) 1318.

${ }^{37}$ In Markazi, the Court addressed a special statute (22 U.S.C. § 8772) that made it clear that the specific assets that were the subject of the group of cases before the Court were subject to legal process. The court held that: (i) the special statute did not violate the separation of powers under the US Constitution because it merely required the application of 'a new legal standard in a pending postjudgment enforcement proceeding', and (ii) the statute was not invalid as providing a rule for a single, pending case because it involved the enforcement of judgment in sixteen pending cases. Markazi (n 34) Syllabus, 1318-19 and 1322-28.

${ }^{38}$ For a regulatory perspective on money laundering and terrorist financing, see section III.F.

${ }^{39}$ This caution is influenced by the experience of one of us (Mooney) in the discussions among counsel for the plaintiffs in Markazi, counsel for certain market participants, and government officials concerning the potential enactment of legislation in this area. That legislation turned out to be the very specific and extremely narrow special statute (22 U.S.C. § 8772) involved in Markazi as opposed to a principled, balanced rule that would accommodate the interests of enforcing creditors more generally while avoiding adverse effects on intermediated holding systems or third parties.
} 
additional risk that an intermediary may become insolvent and unable to perform its obligations - 'intermediary risk'. ${ }^{40}$

At the core of intermediary risk is the possibility that sufficient securities will not be on hand and available to an insolvent intermediary in order to satisfy the proprietary claims of its account holders - ie, a 'shortfall'. A shortfall may arise for different reasons, including poor record keeping, fraud, or the (legitimate) use of client securities by intermediaries. ${ }^{41}$ We suspect that intermediary risk is most acute in non-transparent holding systems. This is so, we hypothesise, because the motivation that underlies the implementation of transparent holding systems is to ensure that account holder claims and securities available to relevant intermediaries are matched, thus guarding against such a shortfall of securities in the event of the insolvency of an account holder's relevant intermediary. ${ }^{42}$ The failure of one or more upper-tier intermediaries might or might not affect the obligations of a relevant intermediary towards its account holders, as the relevant intermediary may or may not be under an obligation to cover any lost holdings resulting from the insolvency of upper-tier intermediaries. Such upper-tier failures also could impact the relevant intermediary's ability to perform its obligations to cover any such losses. Moreover, in some cases a relevant intermediary may escape any otherwise applicable responsibility for upper-tier intermediary failures through contractual waivers or disclaimers - a situation that is not uncommon in the case of cross-border holdings. ${ }^{43}$

A range of measures have been adopted to address intermediary insolvency risk for tiered, intermediated holding systems. Some of these aim to prevent or mitigate this risk and others are aimed at sharing losses in the event of an actual intermediary insolvency and shortfall. Caballero, Johansson, Keijser, and Vermaas have identified several prevention/mitigation measures that are employed outside of insolvency proceedings. ${ }^{44}$ One method for preventing shortfalls is a requirement that every credit to a securities account be matched with a corresponding debit to another account. Another is the regular reconciliation of holdings among issuers, a CSD, and intermediaries in the holding chain. Shortfalls also may be prevented or rectified by appropriate provision for reversing book entries that are invalid or otherwise improper. A shortfall may be eliminated as well by requirements that

\footnotetext{
${ }^{40}$ This risk is also discussed in the chapter by Victoria Dixon in this volume.

${ }^{41}$ If the legitimate use of securities by an intermediary is accompanied by the reduction (debit) of the securities held in the account holder's account (as it the case in, for example, the UK), then a shortfall should not result. But if no such reduction occurs (as may be the case in the US), such use could give rise to a shortfall.

${ }^{42}$ In some transparent intermediated holding systems there may be only one intermediary - the CSD — which would further reduce the likelihood (if not the possibility) that any such intermediary insolvency and shortfall would occur.

${ }^{43}$ For an argument based on this phenomenon, see the chapter by Eva Micheler in this volume.

${ }^{44}$ G Caballero, E Johansson, T Keijser, and M Vermaas, 'Sufficient Securities, Segregation, and Loss Sharing' in T Keijser (ed), Transnational Securities Law (Oxford, Oxford University Press, 2014) ch 7, CE. The following summary is based on their discussion unless otherwise noted.
} 
an intermediary's own, proprietary securities be credited to customer accounts and that an intermediary buy in securities as may be necessary to cure a shortfall. These preventative and corrective measures may be imposed by the relevant regulatory framework for a securities market and its participants. ${ }^{45}$ Shorter settlement cycles also can reduce risk that builds between a trade date and a settlement date and may encourage early identification of shortfalls. Shortfalls also may be discouraged and prevented directly by requiring relevant intermediaries to hold sufficient securities to cover credits to account holder accounts. ${ }^{46}$ Such requirements also may be aided and implemented by segregation rules. ${ }^{47}$ In the event of an actual intermediary insolvency and a shortfall of securities to cover account holder claims, the applicable insolvency law may mitigate the losses of account holders through loss-sharing provisions that allocate losses. ${ }^{48}$ Various other substantive and procedural rules applicable in insolvency proceedings are designed to regularise and enhance recoveries of account holders. ${ }^{49}$

These different mechanisms, techniques, and approaches illustrate the level of complexity needed to accommodate non-transparent holding systems as opposed to transparent ones. A case in point is reconciliation of the total amount of securities issued at the issuer level with the total amount of securities booked to accounts of ultimate account holders. These amounts should coincide (as should the corresponding amounts throughout the holding chain) so as to ensure the integrity of the issue. Any mismatches should be reconciled. Reconciliation, however, requires the cooperation of each intermediary in the chain between the issuer and the ultimate account holder, which is 'typically a time-consuming and labour-intensive process'. ${ }^{50}$ Quicker and simpler reconciliation therefore features prominently in the debate on the application of DLT. ${ }^{51}$

The adoption and implementation of a transparent ITS could provide some obvious benefits in this context, even for non-transparent holding systems and even without any change in law or regulation. Eliminating the information gap by means of a transparent ITS would reduce or eliminate problems of reconciliation of credits of securities on the books of

\footnotetext{
${ }^{45}$ See also the chapter by Christopher Twemlow in this volume.

${ }^{46}$ See Art 24 GSC (n 1) (holding or availability of sufficient securities); Caballero et al (n 44) D; Kanda et al (n 6).

${ }^{47}$ See Art 25 GSC (n 1) (allocation of securities to account holders' rights); Caballero et al (n 44) E; Kanda et al (n 6).

${ }^{48}$ See Art 26 GSC (n 1) (loss sharing in case of insolvency of intermediary); Caballero et al (n 44) F; Kanda et al (n 6). See also C Mooney, 'The Truth about Shortfall of Intermediated Securities: Perspectives under the Geneva Securities Convention, United States Law, and the Future EU Legislation' in PH Conac, U Segna, and L Thévenoz (eds), Intermediated Securities: The Impact of the Geneva Securities Convention and the Future European Legislation (Cambridge, Cambridge University Press, 2013), 160.

${ }^{49}$ See C Mooney and G Morton, 'Harmonizing Insolvency Law for Intermediated Securities: The Way Forward' in T Keijser (ed), Transnational Securities Law (Oxford, Oxford University Press, 2014) ch 8.

${ }^{50}$ CPMI (n 24) 3.2.3.

${ }^{51}$ See eg CPMI (n 24) 3.2.3; ECB Advisory Group (n 20) s 3.
} 
intermediaries with credits on the CSD's books and even those of the issuers. It also could illuminate the existence of shortfalls and trigger remedial actions. Consider an example under the US regulatory regime. Under certain (commonly occurring) circumstances a registered broker-dealer (an intermediary subject to regulation by the Securities and Exchange Commission) need not maintain a 'matched book' in which it maintains securities sufficient to cover those credited to the accounts of its account holders. As explained elsewhere:

'To sum up on the broker-dealer customer protection rules: the combined effect of the possession or control requirement, the hypothecation restriction, and the Reserve Bank Account requirement serves to ensure that a broker-dealer will maintain assets of a value sufficient to protect account holders against any material losses in the case of the brokerdealer insolvency. Although shortfalls are ubiquitous in fact, the Reserve Bank Account addresses the gaps in terms of value, though not in terms of strict matching of securities on an issue-by-issue basis. ${ }^{52}$

As further explained:

'[W]henever the firm [ie, broker-dealer] does not obtain possession or control of a customer security, the firm is generally required to set aside funds in the Reserve Formula. In contrast, as mentioned earlier, the [Securities and Exchange Commission's] Division [of Market Regulation] does not generally allow broker-dealers the option of accepting a higher Reserve Formula deposit requirement in lieu of maintaining possession or control of customer fully-paid and excess margin securities. ${ }^{, 53}$

In this setting of the US customer protection rules, a transparent ITS could identify and quantify the existence, nature, and extent of shortfalls that would trigger the Reserve Fund requirement. Accordingly, the informational advantages of a transparent ITS could be made available without any sacrifice in the flexibility that the US regulatory regime currently provides.

A transparent ITS also could facilitate the operation of an account holder's exercise of its right of set-off and in like fashion protect the interests of insolvent or defaulting issuers of debt securities. ${ }^{54}$ By providing a reliable means of identifying the ultimate account holders of such securities evidentiary issues (troublesome in non-transparent systems) would be resolved. ${ }^{55}$

\footnotetext{
${ }^{52}$ Mooney (n 48), 181-2 (footnote omitted).

${ }^{53}$ MP Jamroz, 'The Customer Protection Rule' (2002) 57 The Business Lawyer 1069, 1122.

${ }^{54} \mathrm{Cf}$ Art 30 GSC (n 1) and UNIDROIT Legislative Guide (n 6) Principle 11.

${ }^{55}$ In similar fashion, the information provided by a transparent ITS would simplify the resolution of the question of discharge of indebtedness in the case of a 'buyback' of debt securities by an issuer. For discussion of both insolvency set-off and debt buy-backs in the context of English law, see the chapter by Louise Gullifer in this volume.
} 


\section{E. Intermediation and conflict-of-laws rules ${ }^{56}$}

Traditional choice-of-law (private international law) rules for a range of issues related to proprietary interests in personal property are a poor fit for intermediated securities. These traditional rules generally have been based on the principle of lex rei sitae. In contrast, for intermediated securities, the law in the US and Europe has embraced a staunch 'no lookthrough' approach that focuses on the relationship (namely, the securities account) between an account holder and its relevant intermediary. The UNIDROIT Legislative Guide aptly describes this approach as the 'tier-by-tier' approach: for each tier of the intermediated chain the applicable law should be determined. ${ }^{57}$ (It also is referred to as the 'place of the relevant intermediary' or 'PRIMA' approach.) This means that each tier in a holding chain with several intermediaries between the issuer and the ultimate account holder may be subject to a different law. It also means that an account holder can look only to its relevant intermediary and cannot 'look through' to the issuer of the securities (and apply the lex societatis) or to the place, if any, where the securities are (or are deemed to be) located under a lex rei sitae analysis. On the international scene, in 2000 the Hague Conference on Private International Law embarked on a project to unify the conflict-of-laws rules for intermediated securities. This project resulted in the 2002/2006 $6^{58}$ Convention on the Law Applicable to Certain Rights in Respect of Securities Held with an Intermediary (Hague Securities Convention, or HSC). ${ }^{59}$ The HSC entered into force in 2017 following ratification by the third State, the US.

There are different variations of the tier-by-tier or PRIMA approach. ${ }^{60}$ In the US (when the HSC is not controlling), this approach is reflected in $\S 8-110(\mathrm{~b})$, (e), and (f) of the UCC, enacted as early as 1994, which takes as its starting point in a waterfall of alternatives the agreement between a securities intermediary and its account holder (in UCC terminology:

\footnotetext{
${ }^{56}$ See the chapter by Philipp Paech in this volume.

${ }^{57}$ UNIDROIT Legislative Guide (n 6) pt VIII, especially 304-05.

${ }^{58}$ The Convention was 'adopted' at a diplomatic Conference in 2002 and 'concluded' as a result of a first signature in 2006. See H Kronke, 'Brüsseler Springprozession: Die Harmonisierung des Rechts zentralverwahrter Finanzinstrumente als Lehrstück über Privatautonomie, Regulierung, Lobbyismus und Verwaltung' in C Stumpf, F Kainer, and C Baldus (eds), Privatrecht, Wirtschaftsrecht, Verfassungsrecht: Privatinitiative und Gemeinwohlhorizonte in der europäischen Integration (Baden-Baden, Nomos, 2015) 759, 762; T Keijser, 'Financial Collateral Arrangements in the European Union: Current State and the Way Forward' (2017) 22 Uniform Law Review 258, fn 20.

${ }^{59}$ R Goode, H Kanda, K Kreuzer, with the assistance of C Bernasconi, Hague Securities Convention: Explanatory Report (Hague Conference on Private International Law, 2017; 2nd ed). See also Goode, Kronke and McKendrick (n 6) 15.91-98, as well as a host of further sources available at https://www.hcch.net/en/instruments/conventions/publications $1 /$ ?dtid=1\&cid=72.

${ }^{60}$ For a comparison of the different approaches, see F Garcimartín and F Guillaume, 'Conflict of Laws Rules' in T Keijser (ed), Transnational Securities Law (Oxford, Oxford University Press, 2014) ch 10; J Rogers, 'Conflict of Laws for Transactions in Securities Held Through Intermediaries', (2006) 39 Cornell International Law Journal 285.
} 
'entitlement holder') to determine the intermediary's jurisdiction, the law of which governs. ${ }^{61}$ In Europe, Article 9(2) of the 1998 Settlement Finality Directive, ${ }^{62}$ Article 24 of the 2001 Directive on the Reorganisation and Winding up of Credit Institutions, ${ }^{63}$ and Article 9 of the 2002 Financial Collateral Directive ${ }^{64}$ instead focus on the account on which an account holder's interests are registered as the relevant connecting factor. ${ }^{65}$ The HSC, in similar fashion to the UCC approach, takes the law agreed in the account agreement between an account holder and its relevant intermediary as its starting point, but subject to a 'qualifying office test' (ie, the intermediary must have an office in the State the law of which is chosen). ${ }^{66}$

All these choice-of-law regimes, despite their variations, thus reject any look-through by an account holder beyond its relevant intermediary, eg, to the issuer or physical certificates, if any. A central point is that look-through to the issuer may be impractical in the context of portfolio financing. If a securities portfolio consists of different types of securities, such as shares issued by issuers organised under several jurisdictions and bonds governed by the laws of several jurisdictions, a transfer could potentially be effected only in accordance with many applicable laws. Moreover, taking the law of the issuer as the relevant connecting factor can lead to complications in the case of substitution or margining arrangements: a different law may apply to each transfer of securities in this context. ${ }^{67}$ Look-through to physical certificates, if any, which are typically held by one or more securities depositories, is likewise impractical (or impossible), because an ultimate account

\footnotetext{
${ }^{61} \S 8-110(\mathrm{e})(1)$ UCC. See Goode, Kronke and McKendrick (n 6) 15.84-6.

${ }_{62}$ Directive $98 / 26 /$ EC.

${ }^{63}$ Directive 2001/24/EC.

${ }^{64}$ Directive 2002/47/EC.

${ }^{65}$ Goode, Kronke and McKendrick (n 6) 15.87-90; Keijser (n 58) s 22. Attempts to come to further harmonisation of the conflict-of-laws (let alone a comprehensive substantive law) regime regarding intermediated securities in the EU appear to have stranded after a saga spanning over fifteen years. On the conflict-of-laws debate see, inter alia, The Giovannini Group, Cross-border Clearing and Settlement Arrangements in the European Union (Brussels, November 2001), 57-9 (Barrier 15: Uneven application of national conflict of law rules); The Giovannini Group, Second Report on EU Clearing and Settlement Arrangements (Brussels, April 2003), 12-13; Legal Certainty Group, Second Advice of the Legal Certainty Group: Solutions to Legal Barriers Related to Post-trading within the EU (August 2008), Introduction 2.3.2, Part I 1.4.2; European Commission, Directorate General Internal Market and Services, Securities Law Legislation: $7^{\text {th }}$ Meeting of the Member States Working Group: Non-paper (Brussels, 15 May 2013), VI; European Central Bank, T2S Harmonisation Steering Group, Conflict of Laws Issues in T2S Markets: a Fact Finding Exercise (10 November 2015); and, upon deliberations in the context of the Capital Markets Union, the recent 'proportionate response' (quote p 6) in the Communication from the Commission to the European Parliament, the Council, the European Economic and Social Committee and the Committee of the Regions on the Applicable Law to the Proprietary Effects of Transactions in Securities (Brussels, 12 March 2018; $\operatorname{COM}(201889$ final). ISDA, in a letter to the European Commission dated 22 May 2018, available at https://www.isda.org/a/sUHEE/ISDA_comment_letter_on_assignment_of_claims_proposal.pdf, remarked: 'We feel compelled to observe that the Commission Communication has missed an important opportunity to deal with a continuing source of substantial legal uncertainty for the financial markets.'

${ }^{66}$ Art 4(1) HSC.

${ }^{67} \mathrm{Eg}$ the substitution of securities X (of an issuer in State A) for securities Y (of an issuer in State B) would require the application of two distinct laws.
} 
holder (let alone its creditors) is unlikely to know (and may be unable to find out, eg, in light of privacy considerations) where such certificates are located. ${ }^{68}$

What would be the potential impact on a State's choice-of-law rules were a State to adopt and implement a transparent ITS for its intermediated holding system? Stated otherwise, how would a transparent ITS affect the operation of existing rules or the prospects for adoption of reforms embracing the tier-by-tier, no-look-through PRIMA approach? Because the PRIMA or tier-by-tier approach is applied to both transparent and nontransparent intermediated holding systems, it is quite plausible that moving from a nontransparent ITS to a transparent ITS would have little or no impact on the operation and application of the choice-of-law rules in such systems. That result would reflect a challenge, or at least an exception, to the thesis we have presented. Nonetheless, it is also plausible that a transparent ITS could facilitate a more informed and strategic exercise of party autonomy under a PRIMA approach such as that provided by the UCC or the HSC. It also could allow more informed investment decisions in connection with holding across borders. For example, an investor in State A could better assess the existence of or potential for shortfalls in the case of holding through a securities account governed by the law of State B if State B provided a transparent ITS. In these contexts more information is better than less information.

Notwithstanding these potential informational benefits of transparent ITSs, we are skeptical that a mere move to a transparent ITS would on balance provide material practical benefits in the specific context of choice-of-law rules for intermediated securities. On the other hand, future developments in securities holding systems that would embrace greater transparency might well have a major impact. For example, in a substantially disintermediated transparent holding system employing DLT it might be necessary to mandate a uniform applicable law for the entire system. That approach would be incompatible with PRIMA/party autonomy or would require a regulatory mandate for the exercise of PRIMA/party autonomy in a uniform manner. ${ }^{69}$

The HSC regime is grounded on the existence of holding systems in which each account holder has an account with a single identifiable relevant intermediary. Would the HSC approach be nimble enough to accommodate the operation of disintermediated DLT-based systems that might be developed in a substantial number of jurisdictions? If not, would a new system for harmonised choice-of-law rules for securities holding be in order?

\footnotetext{
${ }^{68}$ Goode, Kronke and McKendrick (n 6) 15.81-2; Goode et al (n 59) especially Int-38 to Int-40.

${ }^{69}$ On the conflict-of-laws analysis in a DLT setting, see M Kalderon, F Snagg, and C Harrop, 'Distributed Ledgers: A Future in Financial Services?' (2016) 31 Journal of International Banking Law and Regulation, 243, 247-8 ('Conflict of laws'); P Paech, Securities, Intermediation and the Blockchain: An Inevitable Choice between Liquidity and Legal Certainty? (June 2016, updated version; LSE Law, Society and Economy Working Paper 20/2015) IV.D.1.
} 
To make this discussion more concrete, imagine a system based on a disintermediated platform that connects ultimate account holders/investors with issuers of securities. ${ }^{70}$ Participation in the system in any capacity is conditioned on agreement that all related rights and obligations are governed by the law of State X (the 'law of the system'). There is a system operator of the platform (or perhaps multiple operators of various components of the platform and the system), there are various system participants (nodes) that maintain records in a DLT environment, and the role of some system participants is to facilitate the communication of data among investors, issuers, and other system participants. Ultimately, of course, the 'system' is designed to confer on the participating investors the economic benefits of their investments (including the value of the investments, the capacity to dispose of investments, the receipt of distributions of dividends and interest, and exercise of voting rights). ${ }^{71}$ Because this hypothetical system does not employ a single relevant intermediary, however, the HSC would not apply. Consequently, the HSC would not legitimise or oblige the courts of States Parties to the HSC to recognise the applicability of the law of the system.

A different result might be obtained were the HSC to be modified to incorporate the concepts embodied in Article 7 of the GSC. Article 7 provides a mechanism for a Contracting State to declare that "person[s] other than the relevant intermediary [are] responsible for the performance of a function or functions (but not all functions) of the relevant intermediary under this Convention'. ${ }^{72}$ Even with such a modified HSC, however, its core assumptions about a tier-by-tier world of intermediated securities holding may be a poor fit for the disintermediated structures of the future. Perhaps a new instrument or new approach to legitimising the law of a system indeed may be in order.

F. Regulatory Perspectives I: Determining Beneficial Ownership in the Context of Money Laundering, Terrorist Financing, and Other Criminal Activity, as well as Nationally Strategic Enterprises

At one of the meetings of the 'Intermediation and Beyond' working group, Professor Paul Davies noted that shareholders are either pictured as 'victim' (where their rights are eroded in tiered systems) or as 'villain' (where their identity and intentions are hidden behind intermediated or nominee structures). This second representation features in particular in

\footnotetext{
${ }^{70}$ The hypothetical system envisioned in the following discussion bears similarities to a proposed 'New Platform' system in K Koens and CW Mooney Jr, 'Beyond Intermediation: A New (Fintech) Model for Securities Holding Infrastructures' (on file with the authors).

${ }^{71}$ The GSC provides just such a 'functional' approach to the rights to be afforded to an account holder upon the credit to a securities account: GSC (n 1) Art 9.

${ }^{72}$ If such a revision of the $\mathrm{HSC}$ were generally thought to be advisable, it would be wise for the existing three States Parties (Mauritius, Switzerland, and the US) to act promptly in case other States adopt the HSC in the future, which might complicate, delay, or impair the amendment process. See Art 40 Vienna Convention on the Law of Treaties (amendment of multilateral treaties).
} 
the debate on money laundering, terrorist financing, and other instances of illegal activity in the financial system, ${ }^{73}$ and may also be relevant in the context of shareholdings in nationally strategic enterprises.

An important initiative towards the identification of clients and beneficial owners are the 2004 IOSCO Principles on Client Identification and Beneficial Ownership for the Securities Industry ('IOSCO Principles'). ${ }^{74}$ A principal aim of these Principles is the prevention of the illegal use of the securities industry, including by way of securities fraud, market abuse, money laundering, and the financing of terrorism. ${ }^{75}$ More recent international guidelines concerning the detection of money laundering, terrorist financing, and other criminal activity in the financial sector include the International Standards on Combating Money Laundering and the Financing of Terrorism \& Proliferation [of weapons of mass destruction] as updated by the Financial Action Task Force in February 2018 ('FATF Recommendations'). ${ }^{76}$ Specifically for the securities industry, the International Securities Services Association (ISSA) issued the first revised edition of the Financial Crime Compliance Principles for Securities Custody and Settlement in May 2017 ('ISSA Principles'), ${ }^{77}$ in order to address 'money laundering, terrorist financing, market abuse, corruption, fraud and the evasion of sanctions'. ${ }^{78}$ In Europe, money laundering and terrorist financing are currently covered by Directive (EU) 2015/849 on the prevention of the use of the financial system for the purposes of money laundering or terrorist financing ${ }^{79}$ (' $4{ }^{\text {th }}$ Anti-Money Laundering Directive'). ${ }^{80}$ Generally, over the past decades, the matters covered by these initiatives have come under increasing scrutiny of policy makers, resulting in ever stronger requirements regarding know-your-customer rules and transparency, so as to make it possible to detect and address any undesirable behaviour

\footnotetext{
${ }^{73} \mathrm{Eg}$ market manipulation and insider trading: see Council of Europe, Committee of Experts on the Evaluation of Anti-money Laundering Measures and the Financing of Terrorism (MONEYVAL), Typology Research: Use of Securities in Money Laundering Schemes (2008) p 9 ss 4 and 5, p 30 ss 137 et seq, p 66 s 204; Financial Action Task Force (FATF), Report: Money Laundering and Terrorist Financing in the Securities Sector (October 2009) ch 4; Geis (n 14) fn 187 and p 46; and Yermack (n 20) 3.4.

${ }^{74}$ IOSCO, Principles on Client Identification and Beneficial Ownership for the Securities Industry (2004), available at https://www.iosco.org/library/pubdocs/pdf/IOSCOPD167.pdf.

${ }^{75}$ IOSCO Principles (n 74) I.

${ }^{76}$ FATF, International Standards on Combating Money Laundering and the Financing of Terrorism \& Proliferation (2012), available http://www.fatfgafi.org/publications/fatfrecommendations/?hf $=10 \& \mathrm{~b}=0 \& \mathrm{~s}=\mathrm{desc}$ (fatf_releasedate).

${ }^{77}$ ISSA, Financial Crime Compliance Principles for Securities Custody and Settlement (2017), available at https:/www.issanet.org/e/3/current-wgs/compliance-transparency-value-chain/123-compliance-

transparency.html. This website announces that a full revision of the ISSA Principles will be initiated in the course of 2018.

${ }^{78}$ ISSA Principles (n 77) s 1.

${ }^{79}$ Directive (EU) 2015/849 OJ L141/73, amended by Directive (EU) 2018/843 OJ L156/43. The details of the 2018 amendment, which generally consolidates and elaborates on the approach of the original directive, could not be taken into account for the purpose of this chapter.

${ }^{80}$ Art 1 of the $4^{\text {th }}$ Anti-Money Laundering Directive (n 79) defines money laundering and terrorist financing.
} 
effectively. ${ }^{81}$ This section examines three examples of the implications of this tendency for transparency in the intermediated securities holding chain.

A first example of a drive towards transparency in the context of tiered securities holding systems can be found in the 2017 ISSA Principles. ${ }^{82}$ In particular the crime compliance principles regarding 'Third Party Client Business' ${ }^{83}$ contain several instances where an upper-tier intermediary ('Custodian' in ISSA terminology) may be required to look through the chain of one or more lower-tier entities to ultimate beneficiaries. This holds true for both segregated and omnibus account structures. For segregated accounts, ISSA Principles 7 and 8 determine that ' $[\mathrm{w}]$ hen an Account Holder opens a segregated account for a third party with the Custodian, the account must be associated with the name of the third party', while, in addition, 'the Account Holder must declare to the Custodian the Ultimate Asset Ownership of the assets deposited to a segregated Account Holder's account'. In respect of omnibus accounts, ISSA Principles 13 and 14 state that an upper-tier intermediary may under circumstances ('red flags') request its account holder to disclose 'Ultimate Asset Ownership'. ${ }^{84}$ Likewise, in a trading context, under ISSA Principle 17, an upper-tier intermediary may under circumstances require its account holder to look through the chain and provide information on ultimate sellers and buyers of securities. ${ }^{85}$

The mechanism by which upper-tier intermediaries should procure such look-through is on the basis of contracts: 'In order to ensure that the Custodian can meet its obligations and fulfil the objectives of its compliance policies, it should communicate its requirements to its Account Holders and obtain representations and undertakings relating to them contractually. ${ }^{\prime 26}$ The MONEYVAL report envisages a similar approach. Where a securities company relies on intermediaries or other third parties to carry out customer due diligence, including the identification of beneficial owners, this should take place 'by including

\footnotetext{
${ }^{81}$ See FATF Recommendations (n 76) Introduction; ISSA Principles (n 77) Preamble; $4^{\text {th }}$ Anti-Money Laundering Directive (n 79) recital (3). For further background, see MONEYVAL (n 73); FATF Report (n 73); I Paraskevopoulos, The Threat of Money Laundering in Intermediated Securities Systems and Bitcoin Transactions (2017) (LLM thesis International Hellenic University), available at https://repository.ihu.edu.gr/xmlui/bitstream/handle/11544/15826/THESIS\%20ID\%2011041500341.pdf?sequence=1.

${ }^{82}$ The ISSA Principles (n 77) fn 2, explicitly exclude their application to systems with 'direct end investor records at the level of the CSD', and so apply to non-transparent systems only.

${ }^{83}$ ISSA Principles ibid 3.C, p 10-14.

${ }^{84}$ Back in 2004, IOSCO Principle (n 74) 1a, fn 2, still took the approach that in the case of omnibus accounts an upper-tier intermediary (an 'Authorized Securities Service Provider' in IOSCO terminology) 'will not be required to "drill down" through the financial institution [its client] to identify and verify all of the financial institution's clients'. This approach, however, is hard to square with the requirement of IOSCO Principle 2 to identify beneficial owners.

${ }^{85}$ A comparable approach towards transparency may be found in MONEYVAL (n 81) 100-01 ('Reliance on intermediaries and third parties').

${ }^{86}$ ISSA Principles (n 77) 3.C, p 10.
} 
specific clauses in the agreements with intermediaries/third parties or by any other appropriate means' ${ }^{87}$

This contractual approach, however, may not be sufficient. For example, where an intermediary is held to keep its client's positions confidential on the basis of contract or statute, it is impossible for the intermediary to report to upper-tier entities without breaching that contract or statute. This point is developed further below. ${ }^{88}$

A second example of enhanced transparency, regarding primarily equity securities, can be found in the $4^{\text {th }}$ EU Anti-Money Laundering Directive, which requires the establishment of central ultimate beneficial ownership (UBO) registers. ${ }^{89}$ Corporate and other legal entities, as well as trusts, should hold adequate, accurate, and current information on their beneficial ownership, ie, 'any natural person(s) who ultimately owns or controls the customer and/or the natural person(s) on whose behalf a transaction or activity is being conducted' ${ }^{90}$ Such information should be transmitted to and made available in a central register. In the context of intermediated securities systems, this apparently implies that issuers need to look through the intermediated chain to ascertain who their beneficial owners are. It is unclear, however, how the UBO requirements work in the context of long and possibly cross-border intermediated chains and in that of changing ownership as a result of (high frequency) trading. ${ }^{91}$ In such contexts it may be impractical, if not impossible for issuers to continuously keep full track of ultimate beneficial owners, while the available information in the register may well be outdated or otherwise inaccurate. Where no beneficial owner can be identified, or where there is doubt that the person identified is the beneficial owner, the $4^{\text {th }}$ Anti-Money Laundering Directive envisages that the senior managing official(s) are considered as such. ${ }^{92}$ Whereas this approach may well stimulate managers to do their best to identify the 'real' beneficial owners, it does not in all cases guarantee that money laundering and other undesirable behaviour on the financial markets can be identified.

It should be noted that Article 3(6)(a)(i) of the $4^{\text {th }}$ Anti-Money Laundering Directive contains an exception for companies listed on a regulated market, but only if these are

\footnotetext{
${ }^{87}$ MONEYVAL (n 81) 101. Cf IOSCO (n 74) Principle 5 on 'Third Party Reliance'.

${ }^{88}$ Section III.G.

${ }^{89} 4^{\text {th }}$ Anti-Money Laundering Directive (n 79) recitals (12)-(17) and Arts 3(6) and 30-31. These provisions are inspired by (predecessors of) FATF Recommendations 24-5; see also the Interpretive Notes to these Recommendations at pp 84-91.

${ }_{90}^{90} 4^{\text {th }}$ Anti-Money Laundering Directive (n 79) Art 3(6) specifies how this plays out in the context of corporate entities, trusts, and other legal entities and arrangements, including applicable thresholds. See also recital (13) of the Directive. $C f$ the definition of 'Beneficial owner' in the FATF Recommendations (n 76) Glossary, 111 , and also the discussion in the introductory chapter by Louise Gullifer and Jennifer Payne in this volume.

${ }^{91}$ On the trading scenario, $c f$ ISSA Principles (n 77) s 17 (which envisages transparency regarding buyer and/or seller only in case of 'red flags' and after a reasonable period of time).

$924^{\text {th }}$ Anti-Money Laundering Directive (n 79) Art 3(6)(a)(ii).
} 
'subject to disclosure requirements consistent with Union law or subject to equivalent international standards which ensure adequate transparency of ownership information'. In fact, in case the buyer of securities on a regulated market is not the ultimate beneficial owner, the regulatory need to identify that owner may persist. ${ }^{93}$

A third, somewhat different setting in which a similar need for transparency may be perceived is that of certain foreign or other undesirable investments in enterprises that are strategically important from a national perspective (e.g. in the defence, energy, telecom, or other sectors that are considered vital for national security). Such enterprises may well be held privately, but if they have issued securities that are intermediated (e.g. in the context of a privatization, a supply company, or if they carry out a mixture of strategic and nonstrategic activities), authorities may wish to be able to look through the intermediated chain in order to determine who ultimately controls the enterprise. If the information gathered shows that control is not in the 'right hands', mechanisms to end the undesirable situation may include a suspension of voting rights, a forced sale, etc. Look-through, however, may be problematic, in particular in the setting of long, cross-border chains involving foreign intermediaries. ${ }^{94}$

In the three settings discussed (the ISSA requirements, the EU UBO register, and strategic enterprises) applying a look-through approach is problematic. The imposition and enforcement of contractual terms and the establishment of registers of ultimate beneficial owners at best provide only partial solutions. The implementation of a transparent ITS has the potential to solve these problems in so far as identification of holders within the intermediated chain is concerned, but additional mechanisms may be necessary to identify ultimate beneficial owners beyond the chain.

\section{G. Regulatory Perspectives II: Privacy, Data Protection, and Confidentiality}

The drive towards transparency, such as in the context of money laundering, terrorist financing, and other undesirable activity, however, may clash with considerations and obligations regarding privacy, data protection, confidentiality, and (banking) secrecy that inherently hamper transparency. For example, IOSCO Principles 7 and 8 underline that '[n]o domestic secrecy laws, regulations, codes or provisions' should prevent or restrict the

\footnotetext{
${ }^{93} C f 4^{\text {th }}$ Anti-Money Laundering Directive, ibid, Art 16 in conjunction with Annex II(1)(a) on simplified customer due diligence requirements for public companies listed on a stock exchange that are 'subject to disclosure requirements (either by stock exchange rules or through law or enforceable means), which impose requirements to ensure adequate transparency of beneficial ownership'. This provision on companies listed on a stock exchange echoes FATF Recommendations (n 76) 24.B.8.c.iv.

${ }^{94}$ The (problematic) relationship between strategic enterprises and look-through the intermediated chain is addressed in a Dutch draft Bill for the telecom sector, which may be used as a blueprint for other vital sectors. See C Bulten, B de Jong, and EJ Breukink, 'De wet voorkoming ongewenste zeggenschap telecom', (2018) 2 Ondernemingsrecht 99 , especially 3.4 and 6.2 .
} 
collection of information and records by the regulator and, in the context of international cooperation, the provision of client identification information. At the same time, regulators should ensure that data received from foreign regulators are used 'consistent with requirements concerning privacy and data protection'. FATF Recommendation 2 (as revised in February 2018) requires that authorities ensure that domestic cooperation in the field of money laundering and terrorist financing is compatible with 'Data Protection and Privacy rules and other similar provisions (e.g. data security/localisation)', ${ }^{95}$ while Recommendation 9 states: 'Countries should ensure that financial institution secrecy laws do not inhibit implementation of the FATF Recommendations.' The ISSA Principles raise the concern of 'local legal or regulatory requirements that make compliance with the above Principles unlawful without appropriate consents or at all' ${ }^{96}$ Recital (14) and Article 30(5) of the $4^{\text {th }}$ Anti-Money Laundering Directive mention that access to certain beneficial ownership information may need to be 'in accordance with data protection rules'. ${ }^{97}$

Comparable tensions between transparency and privacy etc considerations may occur in other contexts as well. For example, the new provisions of the EU Shareholder Rights Directive $^{98}$ determine that Member States should ensure that the disclosure of information regarding shareholder identity 'is not considered to be in breach of any restriction on disclosure of information imposed by contract or by any legislative, regulatory or administrative provision'. ${ }^{99}$ Moreover, as mentioned above ${ }^{100}$, the circumstance that account holders may not be able to look through the intermediated chain for reasons of privacy, etc., was one of the arguments to advocate for the no-look-through approach in the context of the conflict of laws.

It is apparent from these examples that privacy etc requirements may have a variety of sources, ranging from 'domestic secrecy laws, regulations, codes or provisions' and 'financial institution secrecy laws', 'requirements concerning privacy and data protection' and 'data protection rules', and other 'local legal or regulatory requirements' and 'legislative, regulatory or administrative provision[s]' to 'contract'. This fragmentation is confirmed by analysis published by the ECB on data protection and professional secrecy:

\footnotetext{
${ }^{95}$ See, likewise, in the context of international cooperation, FATF Recommendations (n 76) 40.A.4.

${ }^{96}$ ISSA Principles (n 77) 14.

${ }^{97}$ For a critical assessment of the draft revision of the $4^{\text {th }}$ EU Anti-Money Laundering Directive (n 79), see European Data Protection Supervisor, EDPS Opinion on a Commission Proposal amending Directive (EU) 2015/849 and Directive 2009/101/EC: Access to Beneficial Ownership Information and Data Protection Implications (2 February 2017; Opinion 1/2017). On '[c]ultures of confidentiality', '[c]oncealment' and '[c]ountries with statutory banking secrecy', as factors contributing to money laundering risks, see MONEYVAL (n 81) 77.

${ }^{98}$ Discussed in section III.A above.

${ }^{99}$ Shareholder Rights Directive (n 16) Art 3a(6). See also Art 3a(4) regarding the maximum term of storage of personal data of shareholders.

${ }^{100}$ Section III.E.
} 
while EU law provides rules regarding the protection of personal data of natural persons, ${ }^{101}$ the issue of professional secrecy is largely left to national law. ${ }^{102}$

This issue must be addressed in case of a shift from a system in which information is available only on a tier-by-tier basis to a transparent ITS. Each system should determine in which case what information is available to whom (eg, on the basis of a 'need to know' or 'legitimate interest' standard), and should make sure that the technical platforms involved support the approach taken. ${ }^{103}$

\section{Transparent information technology systems as valuable illumination and as catalyst and roadmap for law reforms}

This section canvasses the potential impact of adopting a transparent ITS as reflected in the various contextual discussions in section III. It also supports our conclusions: First, by making information available throughout the holding structure by means of a transparent ITS (always subject to caveats for privacy and confidentiality concerns), several of the problems identified might be addressed and ameliorated even without changes in laws and regulations. Second, such an informational structure could facilitate and guide the adoption of needed law reforms. This section also considers the potential beneficial influence of transparent ITSs in the inspiration, development, and implementation of future disintermediated holding structures through the application of new technologies.

\section{A. Contexts for Improvements and Reform}

\section{i. Corporate Actions}

It is clear enough that a transparent ITS could facilitate communications and distributions from issuers to ultimate account holders and vice versa. ${ }^{104}$ An issuer's ignorance of the identities of investors or an issuer's lack of access to a reliable means of direct communication with investors could hardly be helpful. If and to the extent that the applicable law or applicable provisions of corporate organic documents or bond contracts adequately and clearly provide directions to issuers concerning corporate actions, adoption of a transparent ITS alone could offer enormous efficiencies and improvements. Even if

\footnotetext{
${ }^{101}$ For natural persons, rights to private life, and protection of personal data are reflected in eg Arts 7 and 8 of the Charter of Fundamental Rights of the European Union, Art 8 of the European Convention on Human Rights, Art 16 of the consolidated Treaty on the Functioning of the European Union, and in Regulation (EU) 2016/679 on the protection of natural persons with regard to the processing of personal data and on the free movement of such data. No such comprehensive framework is available in the EU for legal entities.

${ }^{102}$ See ECB Advisory Group (n 20) 13.1.

${ }^{103}$ Specifically on challenges in the setting of DLT, see CSD Working Group on DLT (n 20) 3.3 and 4.2; CPMI (n 24) 3.3.5; ECB Advisory Group (n 20) 13.2; Geis (n 14) 39 and 46.

${ }^{104}$ See section III.A.
} 
adjustments in the applicable law were necessary, a transparent ITS would ease the burden of an issuer's compliance and reduce or eliminate resistance to such law revision.

\section{ii. Claims against Issuers}

A transparent ITS should identify the ultimate account holder of securities as the party with an economic interest (as opposed to a 'legal title' or 'record' interest) and therefore as the appropriate party to assert claims against an issuer. However, if, for example, the applicable law permits claims to be asserted only by the holders of securities registered on the issuer's books, changes in the applicable law would be required to permit an ultimate account holder's right to claim even if a transparent ITS were adopted and even if the actual identity of this account holder were known and could be proved. ${ }^{105}$ On the other hand, as suggested in the context of corporate actions, a transparent ITS could facilitate modifications of corporate organic documents or bond contracts necessary for the assertion of claims by ultimate account holders.

\section{iii. Upper-Tier Attachment}

In a legal regime that is friendly to upper-tier attachment the adoption of a transparent ITS, if it did not already exist, would facilitate the operation of upper-tier attachment without undue interference with third-party rights or the rights and obligations of intermediaries. ${ }^{106}$ In other legal regimes the implementation of a transparent ITS would pave the way for law reforms that would permit upper-tier attachment without inappropriate disruption of the holding systems. A transparent ITS would eliminate the disruptive factual scenarios which are the bases for the general prohibition of upper-tier attachment.

\section{iv. Intermediary Insolvency Risk and Set-Off Rights}

Information provided to all concerned by a transparent ITS would aid in reconciliation of accounts with intermediaries and the CSD as well as with issuers' books and records. It also would serve to identify the existence and extent of shortfalls and aid in regulatory compliance designed to protect account holders against the insolvency of a relevant intermediary. ${ }^{107}$ These benefits could be achieved without changes in laws or regulations. Transparency also could facilitate the operation of an account holder's exercise of a right of set-off against an issuer of debt securities. ${ }^{108}$ When such a set-off right does not exist or is questionable, a transparent ITS could temper resistance to changes in law that would permit or clarify set-off rights. Moreover, a transparent ITS might encourage changes in

\footnotetext{
105 See section III.B.

106 See section III.C, including the discussion of Art 22 GSC.

107 See section III.D.

108 See section III.D.
} 
law with respect to an intermediary's responsibility for unremedied shortfalls in holdings by its upper-tier intermediaries.

\section{v. Conflict-of-Laws Rules}

By making available more complete information a transparent ITS could permit more informed and strategic decisions on the choice of applicable law by agreement of the parties. ${ }^{109}$ In the cross-border setting, transparency could allow parties to take account of the existence or likelihood of shortfalls. However, so long as tiered intermediated holding systems persist, it is doubtful that adoption of a transparent ITS would be of great moment in this context or lead to changes in law that would eschew the PRIMA/tier-by-tier approach to choice-of-law rules. But closing the information gap through a transparent ITS could encourage the adoption of disintermediated holding systems based on new technologies, such as DLT, as a replacement for (or alternative to) legal constructs that are based on tiers of intermediaries.

vi. Money Laundering, Terrorist Financing, and Related Matters

There are substantial legal requirements in place with respect to monitoring of customers and transparency in the contexts of money laundering, terrorist financing, and strategic enterprises. ${ }^{110} \mathrm{~A}$ transparent ITS would provide assistance with compliance with existing rules and increase the accuracy of information available to issuers, intermediaries, and regulators. A transparent system would offer substantial advantages over reliance on contractual provisions or (imperfect) registers. Moreover, a transparent ITS could encourage and blunt resistance to even stronger provisions by lowering the cost of recordkeeping and disclosures.

vii. Privacy, Data Protection, and Confidentiality

The earlier discussion identified and explored the inherent tension between the goals of transparency and concerns about privacy protection. ${ }^{111} \mathrm{~A}$ transparent ITS would force intermediaries and regulators to confront directly and resolve this tension consistent with applicable laws. This confrontation also would serve to identify conflicts among existing applicable laws that should be resolved and accommodated through law reforms. While we do not propose here to resolve these competing considerations on the merits, any resolution should focus on the competing considerations of the potential availability of useful information to the market participants and stakeholders throughout the holding system,

\footnotetext{
109 See section III.E.

110 See section III.F.

111 See section III.G.
} 
made possible by transparency, and the determination of the parties to which various information actually should be made available and the purposes of such availability.

\section{B. Disintermediation and New Technologies}

Focusing on the attributes and potential of transparency in the context of intermediated holding systems invites conjecture as to potential holding structures beyond the tiered, intermediated systems. Many of the problems encountered in the operation of intermediated holding systems might be addressed through disintermediation and the application of new technologies, such as DLT. ${ }^{112}$ Consider the paradigm offered by Professor Geis:

'If we could snap our fingers and create an ideal stock clearing platform, we would probably abandon paper share certificates - along with the complicated, and multi-layered, distinction between record and beneficial owners. A share of stock would trade electronically, perhaps through brokers and exchanges, but the details of each transfer would be processed by a secured and trusted protocol that specifically identifies each share being exchanged. This information would be rapidly updated (ideally in real-time) and accessible by appropriate parties with the right clearance - or, conceivably, by the public. In short, we would have immediate clearing of stock transfers in a way that preserves precise chain of title.' 113

Current developments in Europe provide some examples of the potential influence of transparency on securities holding systems. First, recently the European Central Bank (ECB) and the Bank of Japan have jointly carried out tests of how DLT might operate in the context of payment and securities settlement systems (the Stella project). ${ }^{114}$ Second, the ECB has announced the consolidation of its TARGET2 platform for cash and TARGET2-Securities (T2S) platform for securities settlement. ${ }^{115}$ If that consolidation were to be combined with the DLT platform as tested in the Stella project, this could lead to a pan-European DLT-based platform for cash and securities settlements. Of course, it is too early to predict the attributes that might emerge from such a system (eg, what functionalities it might have and what information might be available on the relevant

\footnotetext{
${ }^{112}$ For critical discussion of this view, see the chapter by Christopher Twemlow in this volume.

${ }^{113}$ Geis (n 14) 36.

114 The report of phase 1 of the Stella project, focusing mainly on payments, can be found in ECB and Bank of Japan, STELLA: Payment Systems: Liquidity Saving Mechanisms in a Distributed Ledger Environment, available at https://www.ecb.europa.eu/pub/pdf/other/ecb.stella_project_report_september_2017.pdf. Information on phase 2 of the Stella project, focusing on both cash and securities, is available in a communication of the ECB and the Bank of Japan of 27 March 2018 at https://www.ecb.europa.eu/pub/pdf/other/stella_project_leaflet_march_2018.pdf.

115 ECB Press Release (7- December 2017), available at https://www.ecb.europa.eu/press/pr/date/2017/html/ecb.pr171207.en.html. TARGET2 is the Eurosystem's real-time gross settlement system for payments; see https://www.ecb.europa.eu/paym/t2/html/index.en.html. On T2S, see n 18.
} 
nodes). Moreover, there are doubtless many practical hurdles to be overcome by such a system, such as the transition of positions in securities to a DLT setting, given that information on such positions is currently stored on a range of legacy technology systems. Nonetheless, this new infrastructure potentially could lead to a rationalisation of the European markets that proved so difficult to achieve by way of legal reform over the past fifteen to twenty years. ${ }^{116}$ The new infrastructure opens the prospect of significantly enhanced efficiency and transparency for issuers, intermediaries, and account holders/investors in a range of fields, including corporate action processing, claims and attachments, insolvency-related issues (including reconciliation), and determining beneficial ownership for a variety of other purposes. Balancing such developments with privacy and data protection will become increasingly important. A new system might require a reconsideration of the approach to conflict of laws as well. Firms currently acting as securities intermediaries would need to rethink their position in the market based on where their services could add value in this new setting. ${ }^{117}$

\section{Conclusion}

In this chapter we have explained how the imposition of transparency through transparent ITSs could ameliorate prevailing problems that confront the existing tiered, intermediated holding systems. Transparency also could offer a path toward useful law reforms. We do not claim that adoption of a transparent ITS would alone resolve the various legal issues and problems that arise in non-transparent holding systems. But adoption of transparent ITSs would eliminate significant impediments to law reforms that would resolve or materially reduce those problems. As the foregoing discussion illustrates, elimination of the information gap through a transparent ITS could facilitate straightforward solutions. Finally, embracing transparency also could show the way toward disintermediated holding systems of the future.

\footnotetext{
${ }^{116}$ On attempts to come to legal harmonization in the EU, see n 65 and Kronke (n 58). On the potential role of a European platform like T2S, see also Micheler 2014 (n 26) 5.94-104.

${ }^{117}$ For some considerations on the new role of intermediaries in such a context, see Geis (n 14) 37-8. Work in progress by one of us proposes a new platform for disintermediated DLT-based post-settlement holding. See Koens and Mooney (n 70).
} 